Article

\title{
Effects of Place Attachment and Image on Revisit Intention in an Ecotourism Destination: Using an Extended Model of Goal-Directed Behavior
}

\author{
Mei-lan Jin ${ }^{1}$, Youngjoon Choi ${ }^{2, *(\mathbb{C})}$, Choong-Ki Lee ${ }^{3, * \mathbb{C}}$ and Muhammad Shakil Ahmad ${ }^{4}$ (D) \\ 1 School of Business, Guilin Tourism University, Guilin 541006, China; mlking@gltu.edu.cn \\ 2 School of Hotel and Tourism Management, the Hong Kong Polytechnic University, Hong Kong \\ 3 College of Hotel and Tourism Management, Kyung Hee University, Seoul 02447, Korea \\ 4 Department of Management Sciences, COMSATS University Islamabad, Attock 43600, Pakistan; \\ drshakil@ciit-Attock.edu.pk \\ * Correspondence: young.choi@polyu.edu.hk (Y.C.); cklee@khu.ac.kr (C.-K.L.); Tel.: +852-3400-2175 (Y.C.); \\ +82-2-964-2537 (C.-K.L.)
}

Received: 16 August 2020; Accepted: 14 September 2020; Published: 22 September 2020

\begin{abstract}
This study explores the decision-making process of tourists visiting Guilin, China as an ecotourism destination. An extended model of goal-directed behavior with the inclusion of place attachment and destination image is employed to understand tourists' revisit intention. This study finds several substantial variables that contribute to leading the behavioral intention of tourists. Results reveal that tourist attitude, positive anticipated emotion, and perceived behavioral control positively influence desire. Tourist desire to visit a destination is an important predictor of behavioral intention, and desire plays a substantial mediating role between attitude, positive anticipated emotion, perceived behavioral control, and behavioral intention. The image of an ecotourism destination is an important antecedent of attitude, perceived behavioral control, and subjective norm. The destination image indirectly influences behavioral intention through attitude, subjective norm, and perceived behavioral control. Destination image also has a direct effect on place attachment, which in turn influences behavioral intention. Findings provide a theoretical framework of understanding tourist behavior and contribute guidelines for developing sustainable ecotourism for central and local governments.
\end{abstract}

Keywords: model of goal-directed behavior; Guilin; destination image; sustainable development; decision-making process

\section{Introduction}

Tourism is the world's largest economic sector [1]. In particular, China is one of the largest outbound markets and inbound tourism destinations, thereby continuously contributing to the country's economic growth [2]. China provides a stable source of tourists worldwide, who made 131 million international departures in 2017 [2]. China is a popular tourist destination that attracts a large number of international and domestic tourists [1]. In China, inbound tourists reached nearly 300 million in 2018, whereas domestic tourists were 5.5 billion [3]. Seeing the rapid growth in the Chinese tourism industry, the government has emphasized the importance of sustainable tourism [4]. In particular, the "all-for-one tourism" policy integrates all economic and social resources of a region to promote sustainability in the tourism development process [5].

Guilin is one of the earliest developed and the most popular ecotourism destinations in China. Guilin has many popular natural and cultural resources to promote ecotourism. For instance, the Li River of Guilin was designated as a World Heritage Site in 2014 [6] and Yangshuo in Guilin was established as the observation point for scenic views and nature by the United Nations World Tourism 
Organization in 2009 [7]. In addition, Longsheng Longji terraces in Guilin reflect the ancient terrace farming civilization and ethnic ways of life and customs of Zhuang, Yao, and other minority groups [8]. Thus, as a popular ecotourism destination, Guilin is the most popular destination in Southern China, with more than 100 million domestic and international tourists in 2018 [9], and represents one of the most famous ecotourism destinations in China, providing tourists with a rich "Chinese experience" [10]. Guilin's tourism market has rapidly developed after the Chinese exploration, participation, and development periods [11]. To promote sustainable tourism in Guilin, it is important to understand tourists' decision-making processes because maintaining a substantial number of tourists is a necessary condition for sustainable tourism development [12]. In this regard, there is a need to examine how touristic experiences in nature influence key psychological variables that lead to tourists' behavior.

In the sociological and psychological literature, the "attitude-behavior" research paradigm has provided a theoretical foundation to understand individuals' decision-making processes and behaviors [13]. Perugini and Bagozzi [14] proposed a model which provides a comprehensive theoretical basis for in-depth understanding of tourists' behavior, namely a model of goal-directed behavior (MGB). Building upon rational behavior and planned behavior theories, MGB emphasizes the important role of emotions, motivation, and desire in individual behavioral decision-making [14]. In particular, MGB asserts that attitude, subjective norm, perceived behavioral control, positive and negative anticipated emotions, and desire influence individuals' behavior. In the tourism literature, recent studies supported that adding key psychological variables in an extended model of goal-directed behavior (EMGB) can increase the exploratory power of the model [15-17].

In order to explore the decision-making process of tourists visiting Guilin as an ecotourism site, the current study employed EMGB. The unique contribution of this study is to extend MGB by including two key variables (tourism destination image and place attachment) in the model to better understand tourists' experiences and behavior in the context of an ecotourism destination. The findings of this study highlight key factors that influence tourists' intentions to visit the ecotourism site and examines the causal relationships among main constructs in EMGB. In the following section, the relevant literature will be reviewed and synthesized to explain the key concepts of sustainable tourism and propose the EMGB. Then, the process of data collection and analysis will be described. Based on the findings of this study, theoretical and practical implications will be discussed.

\section{Literature Review}

\subsection{Sustainability and Ecotourism}

In tourism, sustainability is considered to have three pillars: environment, economy, and people. In this regard, sustainable tourism is defined as "tourism that is ecologically benign, economically feasible and socially acceptable-is thus contingent on environmental protection and reconciling tourism activities with local socio-economic values" [18] (p. 1000) According to Balmey [19], many concepts related to sustainable tourism provide the definitional basis for ecotourism as well. Focusing on socio-economic aspects of sustainability, Wall [20] asserted that ecotourism is a solution to environmental as well as economic issues, particularly for underdeveloped countries. Hall and Lew [21] argued that ecotourism is not just an "overlap between nature tourism and sustainable tourism", but, instead, it goes beyond by encompassing social dimensions of sustainability.

To promote ecotourism, it is important to consider the interactions and relationships among stakeholders in a destination [22,23]. Beaumont [24] highlighted that ecotourism helps communities in identification of alternate resources for their livelihood, which are more sustainable in terms of benefits to local residents. Multiple benefits of ecotourism were investigated in the literature, which contribute positively towards sustainable conservation of resources, including natural resources, biodiversity, tourism enterprises, and local businesses as well [25]. Likewise, ecotourism is key to making tourism more sustainable by exploring and managing series of tourists' activities to attract more visitors, 
offering them opportunities to interact with nature, and not only preserving flora and fauna in the region, but also allowing incoming tourists and local inhabitants to continue to enjoy the quality of a destination. Hence, understanding tourists' decision-making processes is important to promote the sustainability of an ecotourism destination.

\subsection{Theoretical Framework: EMGB}

To examine tourists' decision-making processes in the context of the ecotourism destination of Guilin, the current study adopted and extended MGB. MGB has been widely used to predict individuals' behavior, developed from the theory of reasoned action and the theory of planned behavior [14]. Although key variables of the theory of reasoned action and theory of planned behavior are included and redefined in MGB, MGB encompasses the role of motivation and emotional factors. Van der Pligt and de Vries [26] emphasize the importance of anticipated affect in relation to behavior. Specifically, MGB establishes causal relationships among seven factors, namely attitude, subjective norm, perceived behavioral control, positive and negative anticipated emotions, desire, and behavioral intention.

An individual supportive or unsupportive response to particular behavior is called attitude [14]. Subjective norm is an emotional approval or objection to an important person performing a specific behavior [14]. Perceived behavioral control refers to an individual's control of external factors, such as time and money, when conducting specific behaviors [14]. Anticipated emotion is an individual's positive or negative emotional expectation before conducting a specific behavior [16]. Desire is a mental state based on motivation, where an individual performs a particular behavior [16]. Behavioral intention is an individual's belief and will to conduct a specific behavior, indicating one's subjective behavioral tendency [16]. Behavioral intention is directly influenced by attitude, subjective norm, and perceived behavioral control [16]. Furthermore, behavioral intention is indirectly influenced by attitude, subjective norm, and perceived behavioral control, and anticipated positive and negative emotions through desire [16]. Previous studies supported that MGB has a better ability to predict behavior, and its application range is more extensive than the theory of planned behavior $[17,27]$.

Perugini and Bagozzi [14] pointed out that MGB can be extended by adding new variables, which are relevant to a given study setting and context, to improve the ability of MGB to predict individual intention or behavior. Several tourism researchers emphasized that key tourism concepts can be added to improve the prediction of tourist behavior $[16,17,27,28]$. New variables in EMGB must (a) reflect specific behavioral characteristics, (b) affect the decision-making process and behavior, and (c) be conceptually independent of existing variables [14]. Previous studies provided empirical evidence of improving the exploratory power of the model by adding appropriate new variables, such as tourist visa reductions [17], responsible gambling strategy awareness [27], environmental concern, perceived customer effects, and environmentally friendly tourism activities [16]. The current study added and tested two key factors in EMGB, tourism destination image, and place attachment, to understand tourists' revisit intention to an ecotourism destination.

\subsection{Effects of Destination Image}

Hunt [29] postulated that destination image is an individual's overall perception of landscape, environment, language, and vision of a place. Similarly, Lin and Huang [30] conceptualized destination image as an individual's perception or associated memory about a particular place. Crouch [31] found that destination image plays an important role in tourist destination selection and influences different aspects of the tourist decision-making process, including information search for destination attractions, evaluation of different destination choices, and finally destination selection. Information search and destination choice are influenced by the tourist's previous experience and memory regarding the destination. Chen and Phou [32] examined the relationship between destination image and tourist intention of destination choice and found that destination image positively influences the tourist destination choice, which is helpful in building the tourist's positive attitude/behavior towards 
the destination. Conversely, the tourist's dissatisfaction with the destination develops a negative destination image that consequently leads to a change in visit plans for that destination [33].

Destination image has been regarded as a key factor to understand the tourist experience and behavior. Early studies defined destination image as the sum of tourists' feelings, thoughts, ideas, and all knowledge concerning tourism destinations [34,35]. Destination image is conceptualized as a multifaceted, subjective, dynamic [36], and interactive concept and therefore measured with multiple dimensions [37]. For example, researchers attempted to capture the sequential development status of destination image: original, induced, and composite images [38]. Composite image, or the comprehensive impression of tourists' original and induced image after the visit, is considered the focus of the destination image. Baloglu and McCleary [34] divided destination image into cognitive, emotional, and overall images. Cognitive image of the tourist is the sum of his two attributes, i.e., collective measure of his belief and knowledge of site physical attributes [39]. Affective image refers to the overall feelings and emotions of tourists toward the destination [35]. Similarly, a tripartite perspective of destination image (i.e., affective, cognitive, and conative image) has been supported in previous studies [40]. In this respect, the present study conceptualized destination image as a multifaceted concept with cognitive and affective images and operationalized as a second-order factor.

Researchers proposed a positive relationship between destination image and attitude [41]. Tourists are inclined to have a positive attitude when they have positive images of the destination [41-44]. In their study on tourists' revisit intention regarding the Oriental Medicine Festival, Song et al. [41] found that the image of Chinese medicine considerably influences tourists' attitudes. Jalilvand et al. [42] showed that destination image has a positive and substantial influence on international tourists' attitudes when visiting Isfahan, Iran. Moreover, destination image is an important factor affecting the decision of tourists to visit or not. Previous studies supported the notion that destination image affects the subjective norm and perceived behavioral control of tourists. Park et al. [43] conducted a study on the decision-making behavior of Chinese students visiting Japan. In this study, the national image of Japan directly or indirectly influenced the attitudes, subjective norm, and perceived behavioral control of Chinese students' intention to visit. Guido et al. [44] conducted a study on the behavior of purchasing organic foods by using theory of planned behavior. They found that the image of organic food has a considerable positive effect on attitudes, subjective norm, and perceived behavioral control. Proposing the effects of destination image on attitude, subjective norm, and perceived behavioral control, we hypothesize that:

Hypothesis (H1a). Destination image will have a positive influence on attitude.

Hypothesis (H1b). Destination image will have a positive influence on subjective norm.

Hypothesis (H1c). Destination image will have a positive influence on perceived behavioral control.

\subsection{Effects of Place Attachment}

Place attachment refers to the emotional and psychological connections formed via interactions between people and specific places, which include tourist destinations [45]. Place attachment theory is developed from place theory and attachment theory. Place attachment is an important concept to understand human-land relations in geography and social psychology. Tuan [46] first discovered an emotional connection between people and their place of residence, which is called topophilia. Attachment theory originates from the relationships between mother and child, person and person, and person and specific things [47]. Therefore, place attachment postulates an emotional relationship between people and places. Williams and Roggenbuck [48] divided place attachment into place dependence and place identity. Place dependence refers to an individual's dependence on the function of the place to achieve certain effects [49]. Place identity possesses individuals' cognitive and emotional attachment to the place as they identify themselves in relation to the place [49]. Researchers also 
measured place attachment in terms of community connectedness and sense of community ownership towards place and nature [50]. Numerous tourism researchers have adopted a multidimensional concept of place attachment to understand tourist experiences and behavior [47,48,51,52]. The continuous interaction of tourists and a tourist destination forms a strong emotional connection. Place attachment is not static but dynamic and changed by time spent and information available [50]. An accurate understanding of the dynamics of place attachment contributes to the development of tourism marketing and strategies. Place attachment is a useful factor to explain how an emotional relationship with a destination affects tourists' attitudes and behaviors.

Veasna, $\mathrm{Wu}$, and Huang [53] studied the behavior of international tourists visiting the World Heritage Sites of Angkor Wat, Cambodia, and Taipei 101, Taiwan. They found that destination image has a considerably positive influence on place attachment. Kaplanidou et al. [54] found a clear relationship between destination image and place dependence in their online study on participants' behaviors during tourism sports celebrations. The image of the celebration positively influenced place dependence. Prayagl and Ryan [55] studied the behavior of business travelers in Mauritius. In this study, as the perception and evaluation of the tourist destination become positive, tourists form an attachment to the destination. In the case of Taiwan Hakka as a tourist attraction, Hou et al. [56] showed that the image perception of cultural tourism positively affects place attachment. Thus, the present study proposes the following hypothesis:

Hypothesis (H2). Destination image will have a positive influence on place attachment.

Place attachment has a substantial influence on tourist behavior. Tsai [47] found that place dependence and place identity positively influenced international tourists' revisits to Singapore. Brown et al. [57] studied the relationships among tourists' place attachment, evaluation of the host country's image, satisfaction, and revisit intention during the 2012 Olympic Games in London. Walker and Chapman [58] found that place attachment contributes positively to pro-environmental activities and is a strong predictor of residents' actions towards their environment. Moreover, Halpenny [59] studied the park visitors' behavioral intentions and found that visitors' place attachment is significantly related with pro-environmental behavioral intention. Kelly [60] asserted that place attachment shapes behavioral intention and motivates local residents to contribute positively to environmental initiatives like volunteering and environmental conservation.

Place attachment was found to have a direct and substantially positive effect on revisit intention. Ramkissoon [61] conducted a survey of tourists visiting the African islands and found that tourists are inclined to revisit these destinations as their attachment to the places intensifies. Hence, the current study posits the following hypothesis:

Hypothesis (H3). Place attachment will have a positive influence on behavioral intention.

\subsection{Factors in MGB Influencing Behavioral Intention}

Numerous tourism studies using MGB have supported the structural relationships among variables including attitude, subjective norm, perceived behavioral control, emotions, desire, and behavioral intention. Huang et al. [62] adopted MGB to understand the willingness of tourists during sudden public health incidents. They found that attitude, positive and negative anticipated emotions, and perceived behavioral control have positive effects on desire.

In recent years, numerous researchers have applied MGB in various domains and revealed that subjective norm, perceived behavioral control, and attitude are contributing factors towards desire formation [63-65]. For example, Esposito et al. [63], using MGB, examined individual physical activity and found subjective norm, perceived behavioral control, and attitude to be significant contributors towards desire to perform physical activity. 
Furthermore, desire had a positive impact on behavioral intention. Similar patterns were found in the study of Ji and Nie [15] on Chinese tourists' gaming intentions through MGB. Song et al. [16] applied MGB to investigate tourists' revisit intention to the Boryeong Mud Festival. Their study found that attitude, subjective norm, and positive anticipated emotion significantly affect desire. Moreover, desire and perceived behavioral control significantly influenced revisit intention, with a high explanatory power of 71.5\% [16]. Lee et al. [28] applied MGB to understand parents' cognition of teenagers' horse riding. They found that perceived behavioral control and positive and negative anticipated emotions significantly affect desire, which strongly influences behavioral intention, with $60.1 \%$ of explanatory power. Note that the negative anticipated emotion used a double negative form (e.g., if I cannot revisit Guilin, then I will be disappointed) to maintain a consistent sentence pattern with other variables, assuming that it has a positive impact on desire.

Hypothesis (H4a). Attitude will have a positive influence on desire.

Hypothesis (H4b). Subjective norm will have a positive influence on desire.

Hypothesis (H4c). Positive anticipated emotion will have a positive influence on desire.

Hypothesis (H4d). Negative anticipated emotion will have a positive influence on desire.

Hypothesis (H4e). Perceived behavioral control will have a positive influence on desire.

Hypothesis (H4f). Perceived behavioral control will have a positive influence on behavioral intention.

Hypothesis (H4). Desire will have a positive influence on behavioral intention.

On the basis of the hypotheses, this study proposes a research model as depicted in Figure 1. Building upon EMGB, this study included destination image and place attachment to examine the decision-making process of tourists in Guilin. Place attachment and destination image were conceptualized as a second-order factor. Place attachment is measured with two dimensions (place dependence and place identity). Destination image is measured with cognitive and affective images.

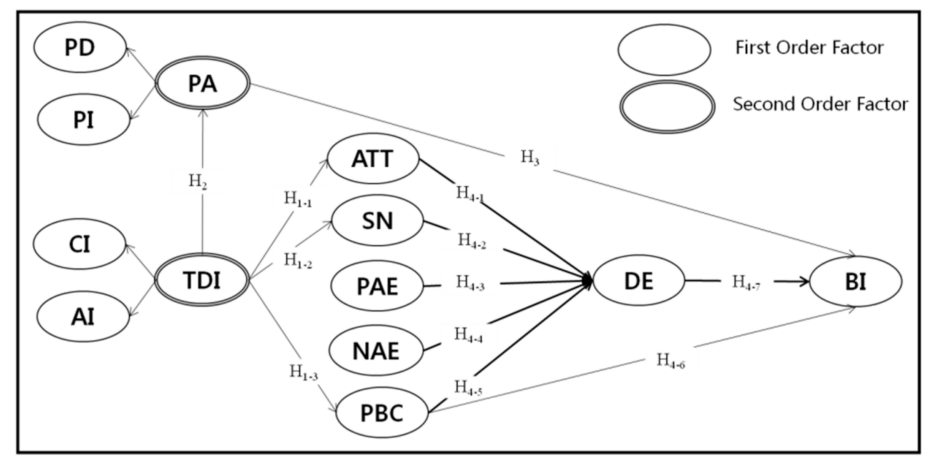

Figure 1. Proposed research model. Note: PD: place dependence, PI: place identity, TDI: tourism destination image, CI: cognitive image, AI: affective image, ATT: attitude, SN: subjective norm, PAE: positive anticipated emotion, NAE: negative anticipated emotion, PBC: perceived behavioral control, DE: desire, BI: behavioral intention.

\section{Research Method}

\subsection{Study Setting: Guilin}

As shown in Figure 2, Guilin has popular ecotourism resources and strategically promotes the sustainable development of ecotourism [5]. For instance, karst caves and landforms are popular 
scenic spots providing unique tourist experiences. Tourists are allowed to enter the karst caves, view stalactites, and learn about karst landforms. Known as one of the 15 most beautiful rivers in the world [66], the Lijiang River Scenic Zone in Guilin ("Li River" hereafter) is famous for its exquisite mountains and water basins, where tourists can enjoy the scenery and be close with nature. In 2004, Guilin Yangshuo became the first Global Observatory on Sustainable Tourism in China, established by the United Nations World Tourism Organization [7]. In 2014, the Li River was included in the World Natural Heritage List, recognizing its natural beauty and value of karst landforms. Moreover, rice terraces in Guilin Longsheng were designated as a Globally Important Agricultural Heritage System in 2010 by the Food and Agriculture Organization of the United Nations. Traditional methods of cultivation have been well preserved and provide tourists with unique experiences of observing how diversified planting modes and landscape patterns considerably increase the diversity of species. With its rich natural and cultural resources, Guilin is a popular destination for tourists who have primary travel motivations of enjoying and experiencing nature.

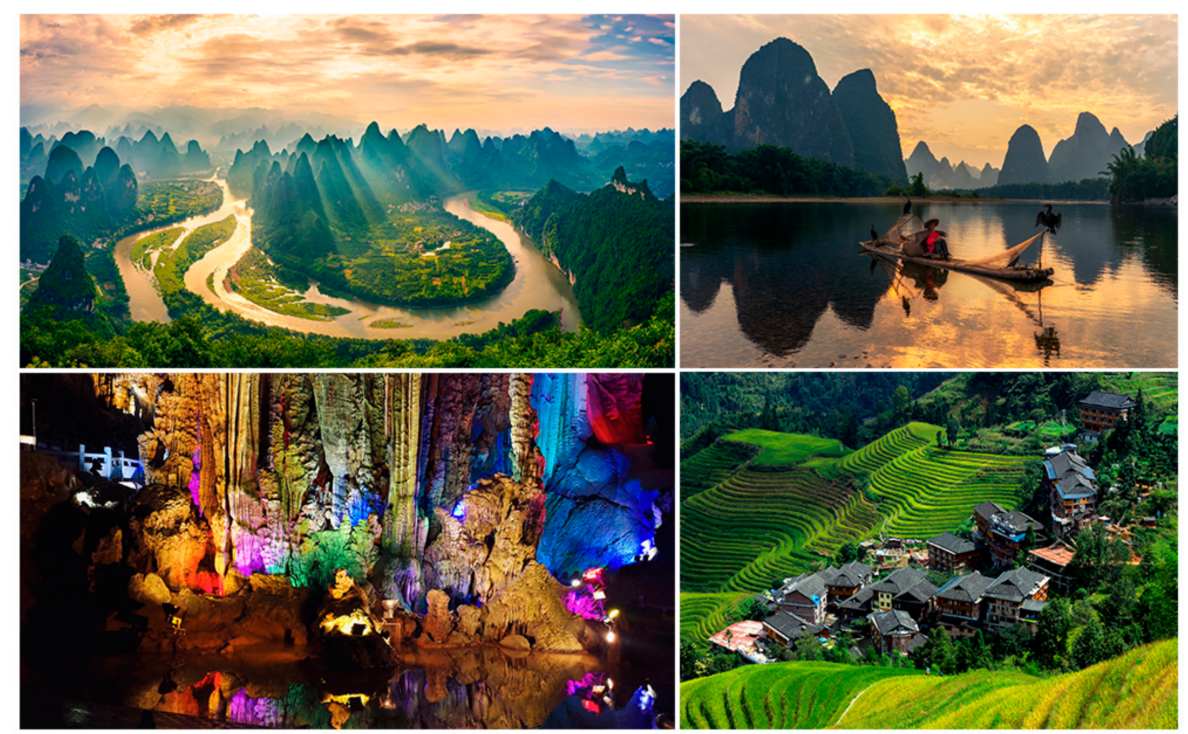

Figure 2. Ecotourism resources and scenic views of Guilin. Note: Li River (top left and right); karst cave (bottom left); rice terraces (bottom right); the pictures are courtesy of Shanghai Tuchong Network Technology Co., LTD of China.

\subsection{Measures}

Destination image consisted of 2 dimensions, including cognition image and affective image, with 4 items each [67]. Place attachment consisted of place identity and place dependence with 3 items each [68]. The measurement items for 7 constructs in MGB were adopted from previous studies [14,16,17], including attitude with 3 items, subject norms with 3 items, perceived behavioral control with 3 items, positive anticipated emotion with 4 items, negative anticipated emotion with 4 items, desire with 4 items, and behavioral intention with 4 items. All items were measured on a 5-point Likert scale ranging from "strongly disagree" to "strongly agree." For content validity experts in the area were invited to review these items. Thereafter, a pre-test was conducted with 40 tourists to ensure the readability of the questionnaire. Certain unclear items were modified for clarity.

\subsection{Data Collection and Analysis}

An onsite survey was conducted with tourists visiting Guilin from 1 October to 16 October 2017. A self-administered questionnaire was distributed to tourists by ten well-trained field researchers who are doctoral students majoring in tourism management. The field researchers contacted tourists in several scenic spots, such as the Li River, Xi Street, Sliver Cave, and Elephant Trunk Hill, which are 
popular ecotourism sites in Guilin. After confirming that a potential respondent spent enough time to explore ecotourism attractions in Guilin, the field researchers shared the purpose of the study with respondents and invited them to the survey. Using convenient sampling method, 506 questionnaires were collected. However, only 486 responses were used in the analysis after excluding 20 incomplete responses.

SPSS 19.0 and AMOS 22.0 were used to analyze the data. This study analyzed the measurement model by using confirmatory factor analysis (CFA) and a structural equation model (SEM) to examine the cause-and-effect relationships among constructors in the MGB model.

\section{Results}

\subsection{Respondents' Profile}

A total of 257 male (52.9\%) and 229 female (47.1\%) tourists participated (Table 1). The largest proportion of respondents were aged from 20 to 29 years old (43\%), followed by 30 to 39 years old (27\%), under 20 years old (13.8\%), 40 to 49 years old ( $7.8 \%$ ), and 50 to 59 years old (4.5\%). Respondents over 60 years old were the smallest group (3.9\%). The majority of respondents had 4-year university degrees $(54.7 \%)$, followed by 2-year college degree holders $(18.1 \%)$, high school graduates $(15.4 \%)$, and undergraduate students (18.1\%). Relatives (39.1\%) and friends (38.3\%) accounted for nearly $80 \%$ of travel companions, followed by solo travelers $(10.1 \%)$, groups $(7.8 \%)$, or with others $(4.7 \%)$. For the purpose of visit, $68.7 \%$ of respondents selected "leisure and vacation." The remainder of respondents opted for "visiting relatives and friends" (10.3\%), "business" (6.1\%), "health treatment" (1.2\%), "food" $(7 \%)$, and others $(6.7 \%)$.

Table 1. Respondents' Profile.

\begin{tabular}{|c|c|c|c|c|c|c|c|}
\hline \multicolumn{2}{|r|}{ Variable } & \multirow{2}{*}{$\begin{array}{l}n \\
257\end{array}$} & \multirow{2}{*}{$\begin{array}{l}\% \\
52.9\end{array}$} & \multicolumn{2}{|c|}{ Variable } & \multirow{2}{*}{$\begin{array}{l}n \\
67\end{array}$} & \multirow{2}{*}{\begin{tabular}{|l|}
$\mathbf{\%}$ \\
13.8
\end{tabular}} \\
\hline & Male & & & \multirow{6}{*}{ Age } & $<20$ & & \\
\hline Gender & Female & 229 & 47.1 & & $20-29$ & 209 & 43.0 \\
\hline \multirow{4}{*}{ Education level } & High school & 75 & 15.4 & & $30-39$ & 131 & 27.0 \\
\hline & 2-year college & 88 & 18.1 & & $40-49$ & 38 & 7.8 \\
\hline & 4-year university & 266 & 54.7 & & $50-59$ & 22 & 4.5 \\
\hline & Undergraduate & 57 & 11.8 & & 60 s or over & 19 & 3.9 \\
\hline \multirow{6}{*}{ Purpose of visit } & Leisure and vacation & 334 & 68.7 & \multirow{6}{*}{ Company } & Relatives & 190 & 39.1 \\
\hline & Visiting relatives and friends & 50 & 10.3 & & Friends & 186 & 38.3 \\
\hline & Business & 30 & 6.1 & & Solo travelers & 49 & 10.1 \\
\hline & Health treatment & 6 & 1.2 & & Groups & 38 & 7.8 \\
\hline & Food & 34 & 7.0 & & Others & 23 & 4.7 \\
\hline & Others & 32 & 6.7 & & Total & 486 & 100 \\
\hline
\end{tabular}

\subsection{Measurement Model}

A two-step approach was used to test the proposed research model. First, this study conducted CFA to test the measurement model, followed by SEM to examine the proposed relationships among latent variables. Table 2 reveals the results of CFA. Goodness-of-fit indices of the measurement model were acceptable $(\mathrm{CMIN} / \mathrm{DF}=2.055(<3), \mathrm{GFI}=0.898($ close to 0.9$), \mathrm{RMSEA}=0.044(<0.08)$, $\mathrm{NFI}=0.911(>0.9), \mathrm{NNFI}=0.946(>0.9), \mathrm{CFI}=0.952(>0.9)[68,69]$. The fitness index is in line with the reference value range, although the GFI is close to 0.90 . Factor loading of observed variables ranged from 0.612 to 0.891 and average variance extracted (AVE) ranged from 0.528 to 0.811 (Table 3), which is greater than 0.5 , thereby confirming convergent validity. Each factor has high internal reliability (Cronbach's $a=0.82-0.94 ;$ composite reliability $=0.715-0.923$ ) [69]. 
Table 2. Results of Confirmatory Factor Analysis.

\begin{tabular}{|c|c|c|c|c|c|}
\hline \multicolumn{2}{|c|}{ Figure } & Items & $\begin{array}{l}\text { Factor } \\
\text { Loading }\end{array}$ & $\begin{array}{l}\text { Cronbach's } \\
\text { Alpha }\end{array}$ & $\begin{array}{l}\text { Composite } \\
\text { Reliability }\end{array}$ \\
\hline \multirow{3}{*}{\multicolumn{2}{|c|}{$\begin{array}{l}\text { Attitude } \\
\text { (ATT) }\end{array}$}} & I think visiting Guilin is a positive behavior. & 0.735 & \multirow{3}{*}{0.90} & \multirow{3}{*}{0.818} \\
\hline & & I think visiting Guilin is a valuable behavior. & 0.800 & & \\
\hline & & I think visiting Guilin is a beneficial behavior. & 0.792 & & \\
\hline \multirow{3}{*}{\multicolumn{2}{|c|}{$\begin{array}{l}\text { Subjective norm } \\
\text { (SN) }\end{array}$}} & Most people who are important to me understand that I visit Guilin. & 0.770 & \multirow{3}{*}{0.91} & \multirow{3}{*}{0.843} \\
\hline & & Most people who are important to me support that I visit Guilin. & 0.812 & & \\
\hline & & Most people who are important to me agree that I visit Guilin. & 0.823 & & \\
\hline \multirow{3}{*}{\multicolumn{2}{|c|}{$\begin{array}{l}\text { Perceived behavioral control } \\
\text { (PBC) }\end{array}$}} & I have sufficient resources (money) to visit Guilin. & 0.650 & \multirow{3}{*}{0.94} & \multirow{3}{*}{0.764} \\
\hline & & I am capable of visiting Guilin. & 0.732 & & \\
\hline & & I am confident that I can visit Guilin if I want to. & 0.891 & & \\
\hline \multirow{4}{*}{\multicolumn{2}{|c|}{$\begin{array}{l}\text { Positive anticipated emotion } \\
\text { (PAE) }\end{array}$}} & If I revisit Guilin, I will be excited. & 0.854 & \multirow{4}{*}{0.93} & \multirow{4}{*}{0.910} \\
\hline & & If I revisit Guilin, I will be glad. & 0.882 & & \\
\hline & & If I revisit Guilin, I will be satisfied. & 0.833 & & \\
\hline & & If I revisit Guilin, I will be happy. & 0.823 & & \\
\hline \multirow{4}{*}{\multicolumn{2}{|c|}{$\begin{array}{l}\text { Negative anticipated emotion } \\
\text { (NAE) }\end{array}$}} & If I cannot revisit Guilin, I will be angry. & 0.853 & \multirow{4}{*}{0.85} & \multirow{4}{*}{0.923} \\
\hline & & If I cannot revisit Guilin, I will be disappointed. & 0.875 & & \\
\hline & & If I cannot revisit Guilin, I will be worried. & 0.880 & & \\
\hline & & If I cannot revisit Guilin, I will be sad. & 0.857 & & \\
\hline \multirow{4}{*}{\multicolumn{2}{|c|}{$\begin{array}{l}\text { Desire } \\
(\mathrm{DE})\end{array}$}} & I would like to revisit Guilin. & 0.856 & \multirow{4}{*}{0.93} & \multirow{4}{*}{0.888} \\
\hline & & I want to have fun when I revisit Guilin. & 0.778 & & \\
\hline & & I hope to revisit Guilin. & 0.879 & & \\
\hline & & I want to experience an unforgettable memory when I revisit Guilin. & 0.747 & & \\
\hline \multirow{4}{*}{\multicolumn{2}{|c|}{$\begin{array}{l}\text { Behavioral intention } \\
\text { (BI) }\end{array}$}} & I will make an effort to revisit Guilin in the near future. & 0.792 & \multirow{4}{*}{0.89} & \multirow{4}{*}{0.860} \\
\hline & & I intend to revisit Guilin. & 0.757 & & \\
\hline & & I am willing to revisit Guilin. & 0.710 & & \\
\hline & & I am willing to spend time and money to revisit Guilin. & 0.855 & & \\
\hline \multirow{8}{*}{$\begin{array}{c}\text { Tourism } \\
\text { destination image } \\
\text { (TDI) }\end{array}$} & \multirow{4}{*}{$\begin{array}{l}\text { Cognitive } \\
\text { image }\end{array}$} & Unpolluted/unspoiled environment. & 0.678 & \multirow{4}{*}{0.83} & \multirow{4}{*}{0.755} \\
\hline & & Atmosphere of leisure. & 0.624 & & \\
\hline & & Interesting cultural/historical attractions. & 0.632 & & \\
\hline & & Beautiful scenery/natural attractions. & 0.696 & & \\
\hline & & Sleepy/arousing. & 0.685 & & \\
\hline & Affective image & Gloomy/exciting. & 0.790 & 0.85 & 0.807 \\
\hline & Afrective image & Distressing/relaxing. & 0.707 & 0.85 & 0.807 \\
\hline & & Unpleasant/pleasant. & 0.682 & & \\
\hline & & I enjoy visiting Guilin and its environment more than any & 0.702 & & \\
\hline & Place & $\begin{array}{l}\text { other destinations. } \\
\text {. }\end{array}$ & & 0.82 & 0.715 \\
\hline Place & dependence & $\begin{array}{l}\text { For recreation/leisure activities, Guilin is the best. } \\
\text { Doing leisure activities in Guilin is more important than in any }\end{array}$ & 0.772 & & \\
\hline attachment(PA) & & other places. & 0.676 & & \\
\hline & & I feel a strong sense of belonging to Guilin. & 0.612 & & \\
\hline & Place identity & I identify strongly with Guilin. & 0.859 & 0.84 & 0.806 \\
\hline & & I feel that I can be myself when I visit/am in Guilin. & 0.842 & & \\
\hline
\end{tabular}

Goodness of fit: $\mathrm{CMIN}=1086.960, \mathrm{DF}=529, \mathrm{CMIN} / \mathrm{DF}=2.055, \mathrm{GFI}=0.898, \mathrm{NNFI}=0.946, \mathrm{CFI}=0.952$, RMSEA $=0.044, \mathrm{NFI}=0.911, \mathrm{RMR}=0.032$.

Table 3. Correlations and AVE (Average Variance Extracted) of Latent Variables.

\begin{tabular}{cccccccccc}
\hline Constructs & ATT & SN & PAE & NAE & PBC & DE & BI & TDI & PA \\
\hline ATT & $\mathbf{0 . 7 4 4}$ & $(0.408)$ & $(0.417)$ & $(0.107)$ & $(0.146)$ & $(0.347)$ & $(0.259)$ & $(0.456)$ & $(0.293)$ \\
\hline SN & 0.639 & $\mathbf{0 . 7 6 1}$ & $(0.285)$ & $(0.110)$ & $(0.111)$ & $(0.220)$ & $(0.191)$ & $(0.321$ & $(0.163)$ \\
\hline PAE & 0.646 & 0.534 & $\mathbf{0 . 8 1 1}$ & $(0.231)$ & $(0.110)$ & $(0.640)$ & $(0.415)$ & $(0.517)$ & $(0.250)$ \\
\hline NAE & 0.327 & 0.332 & 0.481 & $\mathbf{0 . 7 6 7}$ & $(0.032)$ & $(0.174)$ & $(0.242)$ & $(0.187)$ & $(0.233)$ \\
\hline PBC & 0.382 & 0.333 & 0.332 & 0.180 & $\mathbf{0 . 6 6 6}$ & $(0.132)$ & $(0.161)$ & $(0.216)$ & $(0.095)$ \\
\hline DE & 0.589 & 0.469 & $0.800 * *$ & 0.417 & 0.363 & $\mathbf{0 . 7 6 1}$ & $(0.661)$ & $(0.444)$ & $(0.289)$ \\
\hline BI & 0.509 & 0.437 & 0.644 & 0.492 & 0.401 & $0.813 *$ & $\mathbf{0 . 6 6 0}$ & $(0.367)$ & $(0.475)$ \\
\hline TDI & 0.675 & 0.567 & 0.719 & 0.433 & 0.465 & 0.666 & 0.606 & $\mathbf{0 . 6 1 3}$ & $(0.406)$ \\
\hline PA & 0.541 & 0.404 & 0.500 & 0.483 & 0.308 & 0.538 & 0.689 & 0.637 & $\mathbf{0 . 5 2 8}$ \\
\hline
\end{tabular}

Note: The diagonal numbers in bold are the AVE values, the lower numbers are the correlation coefficients between constructors, and the upper numbers are squared correlation coefficients; ${ }^{*}$ is the largest correlation coefficient; ${ }^{* *}$ is the second largest correlation coefficient.

Discriminant validity was tested by using the most rigorous e method of comparing the AVE and squared correlation coefficient $\left(\mathrm{\gamma}^{2}\right)$ of the factors. If $\mathrm{AVE}>\mathrm{\gamma}^{2}$, then discriminant validity is supported. 
Table 3 indicates the correlations between the factors and AVE scores. The correlation coefficient between desire and BI was the highest $(\mathrm{X}=0.813)$. However, the AVE of desire $(0.660)$ was smaller than the squared correlation coefficient between desire and behavioral intention $\left(\gamma^{2}=0.661\right)$. Thus, the discriminant validity between desire and behavioral intention can be judged further to see if the confidence interval does not contain 1 . If the confidence interval $\left(\gamma^{2} \pm 2 \times\right.$ standard error) of two constructors does not contain 1, then discriminant validity between the constructors is supported. The confidence interval of desire and BI ranged from 0.740 to 0.879 ; thus, discriminant validity was supported $[68,70]$. The second largest correlation coefficient between desire and positive anticipated emotion of the correlation was 0.800 , whose squared value $\left(\gamma^{2}=0.640\right)$ is less than the AVE of desire (0.761) and the AVE of positive anticipated emotion (0.811). Thus, discriminant validity was supported between desire and positive anticipated emotion. The AVEs of other constructs were greater than the squared correlation coefficients (AVE $>\gamma^{2}$ ), thereby supporting discriminant validity.

\subsection{Structural Model and Hypothesis Testing}

The structural model had acceptable fit in terms of absolute fit index $(\chi 2(\mathrm{CMIN} / \mathrm{DF})=1410(2.084)$, $\mathrm{GFI}=0.868, \mathrm{RMSEA}=0.047)$ and incremental fit index $(\mathrm{NFI}=0.878, \mathrm{NNFI}=0.933, \mathrm{CFI}=0.932)$, although GFI and NFI were close to 0.9 [71].

Figure 3 shows the structural relationships among latent variables in the EMGB. Destination image positively influenced attitude $(\beta=0.811, p<0.001)$, subjective norm $(\beta=0.689, p<0.001)$, and perceived behavioral control $(\beta=0.441, p<0.001)$. Thus, Hypothesis (H1a), Hypothesis $(\mathrm{H} 1 \mathrm{~b})$, and Hypothesis (H1c): were supported. Destination image also positively influenced place attachment ( $\beta=0.670, p<0.001)$, thereby making Hypothesis (H2) acceptable. Attitude $(\beta=0.109, p<0.05)$, positive anticipated emotion $(\beta=0.678, p<0.001)$, and perceived behavioral control $(\beta=0.076, p<0.05)$ positively affected desire, thereby making Hypothesis ( $\mathrm{H} 4 \mathrm{a})$, Hypothesis $(\mathrm{H} 4 \mathrm{c})$, and Hypothesis $(\mathrm{H} 4 \mathrm{e})$ acceptable. Perceived behavioral control $(\beta=0.077, p<0.05)$ and desire $(\beta=0.624, p<0.001)$ positively affected behavioral intention, thereby making Hypothesis (H4f) and Hypothesis $(\mathrm{H} 4 \mathrm{~g})$ acceptable. Place attachment $(\beta=0.332, p<0.001)$ positively affected behavioral intention, thereby making Hypothesis (H2) acceptable. The model's explanatory power for behavioral intention reached $74 \%$. However, the effects of subjective norm and negative anticipated emotion on desire were not significant, thereby rejecting Hypothesis (H4b) and Hypothesis (H4d).

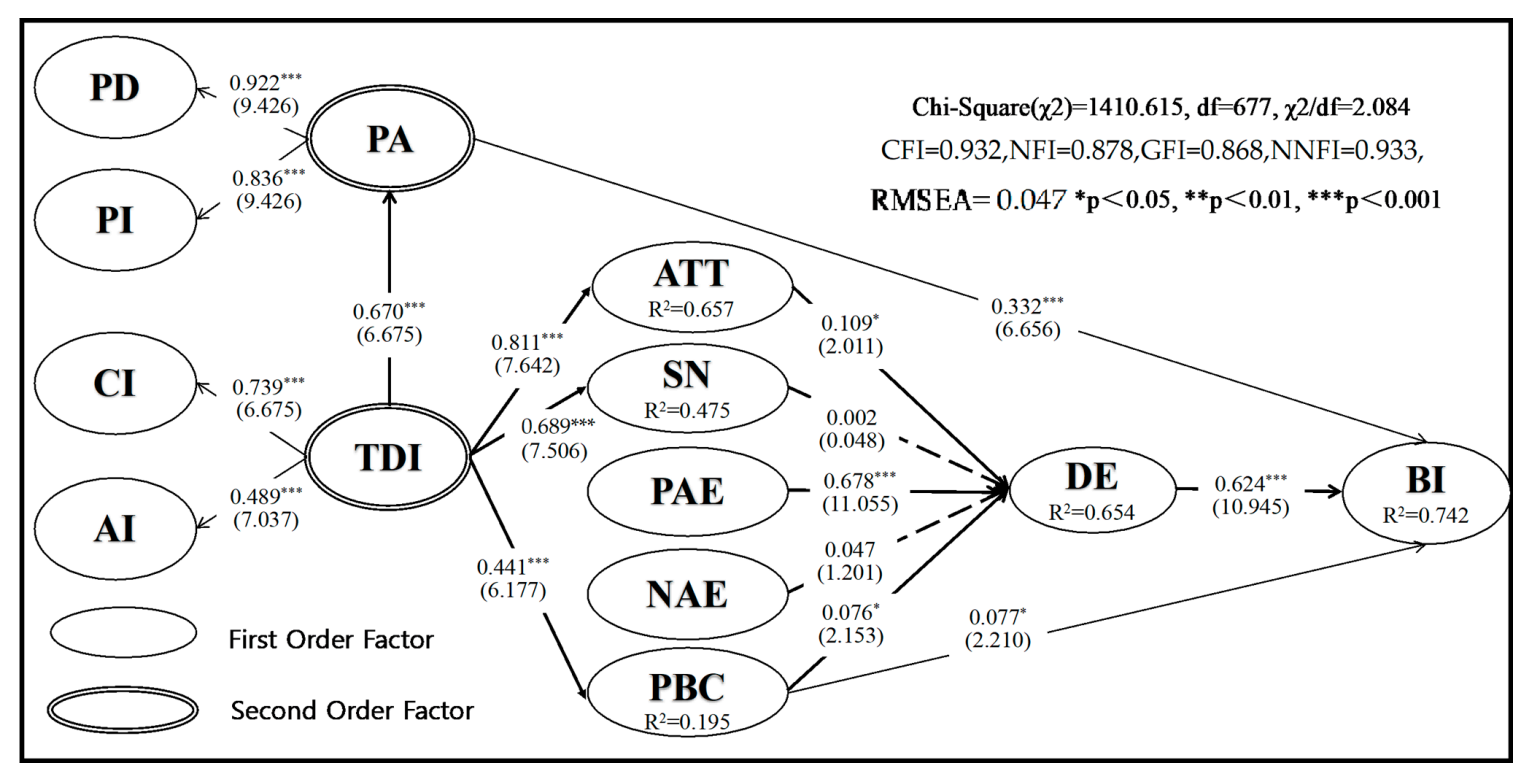

Figure 3. Results of SEM. 


\section{Conclusions and Implications}

This study attempted to understand the decision-making process of tourists in conjunction with sustainability. EMGB was developed by including two important variables for tourists: destination image and place attachment. Unlike other types of tourists (e.g., urban tourists, dark tourists, and business tourists), travel motivations and attitudes of tourists are closely related to the destination image of unpolluted nature and a sense of attachment to a particular destination. Moreover, this study revealed that not only tourists' rational but also their emotions in an ecotourism destination influence revisit intention. By examining the case of tourists' experience in the nature of Guilin, the study findings provide meaningful theoretical and practical implications. The contribution of this study to the tourism literature is threefold. Firstly, the findings provide a theoretical framework for understanding tourist behavior and contribute to developing guidelines for sustainable ecotourism for the central and local governments. Secondly, the findings emphasize the role of destination image and place attachment to increase the tourist's environmental sensitivity and thus make an ecotourism destination economically viable and culturally appropriate. Thirdly, the consideration of sustainability goals of ecotourism (i.e., environmental, socio-cultural, and economic sustainability) provides practical implications to promote sustainable tourism in the region.

The findings reveal that EMGB is a useful theoretical framework to understand tourists' revisit intentions. EMGB successfully accounted for cognitive, emotional, and motivational factors. In line with previous EMGB studies $[16,17,27]$, this study supports that adding key psychological variables to MGB can increase the predictability of tourists' revisit intentions. The findings showed that destination image and place attachment are key psychological factors to understand tourists' decision-making in the ecotourism destination by reflecting the unique tourism destination characteristics of Guilin. Similar to the findings of previous studies [31-33], this study supports that destination image influences tourists' destination choices. Destination image had a direct effect on place attachment, attitude, and perceived behavioral control. Destination image also had an indirect effect on behavioral intention through place attachment, attitude, perceived behavioral control, and desire $(\beta=0.333=0.670 \times 0.332$ $+0.441 \times 0077+0.624 \times 0.124, p<0.05$ ). In addition, place attachment is an important variable to predict tourists' activities and behavior, particularly in the case of ecotourism [57-59]. In a similar fashion, this study revealed that place attachment positively influences tourists' intention to revisit.

The findings confirmed the important roles of key factors in MGB. Tourism researchers postulated that emotional factors are important in the sustainable development of ecotourism destinations [14]. Similarly, this study found that positive anticipated emotion had the strongest effect on desire. The present study showed that positive anticipated emotion substantially affects desire, supporting the notion that the emotional variable is the main factor in choosing an ecotourism destination. Perceived behavioral control directly influenced desire and had direct and indirect effects on behavioral intention. In the present study, however, the effects of subjective norm and negative anticipated emotion on desire were not substantial. One potential explanation of this finding may be attributable to a suppression effect. The results are similar to the study of Huang et al. [62] indicating that the effect of subjective norm is not significant. This finding may be explained by the fact that tourist behavior is not strongly affected by others, and desire originates from tourists themselves. The findings may reflect that the fundamental purpose of ecotourism is associated with intrapersonal motivations. By extending MGB, one important contribution of this study is to provide a comprehensive picture to illustrate the complex interrelationships between key factors in MGB and destination image and place attachment.

In addition, the present study provides useful practical implications for the sustainable development of Guilin's ecotourism. The enhancement of positive anticipated emotion and enjoyable tourist experiences may complement the effect of external constraints, such as time and funds. Local travel agencies should ensure that the emotional expectation of tourists visiting Guilin can provide a good experience. The ecological image of Guilin is popular in China because rivers and mountains in Guilin are introduced in Chinese primary school textbooks. Emerging technologies (e.g., virtual reality and augmented reality) can be used as powerful destination marketing tools. Such marketing 
tools can be used for entertainment and enjoyment, which leads to an increase positive anticipated emotion. Such marketing efforts can be developed to continually attract tourists to the natural and cultural beauty of Guilin. Moreover, a significant positive relationship between positive anticipated emotion and desire has meaningful practical implications for marketers. This finding suggests that tourism marketers should take the responsibility to make visitors/tourists feel excited and happy so that their desire should motivate them to visit that destination again. As behavioral intention is predicted by desire, tourism can be sustained by keeping the tourist's desire alive. For successful destination promotion, local governments should understand tourist desire in an ecotourism destination. Unlike urban tourism, ecotourists tend to have a strong desire to enjoy and appreciate the nature and culture. Developing marketing strategies to appeal ecotourist desire would be the key for the sustainable ecotourism in Guilin. Moreover, positive behavioral control was found to be significantly related to behavioral intention and desire. Tourists' volitional control mechanism may be one of the key predictors of destination choice; therefore, there is a need for marketers to understand the psychological mechanism between desire and behavioral intention.

Constructing positive and concrete destination images from tourists' on-site experiences is important. However, the perception of destination image is dynamic [52]. Destination image in tourists' minds can be changed as tourists gain further insights from their visits and as time progresses. Tourism marketing should reduce exaggerated slogans and photographs to maintain consistency and unity of the destination image. This suggestion can improve the emotional connection of tourists with destinations. The smaller the image perception gap is between pre and post visit by tourists, the closer the emotional connection is to the place. Tourists' feelings toward destinations are created from what they see, hear, and feel during their travels. Previous studies found that a positive image of uniqueness and authenticity $[52,54]$ and strong memories created in a destination $[54,55]$ become triggers to enhance tourists' cognitive and emotional attachment to the destination. Unique tourism features of Guilin can be used to enhance place attachment. For instance, the performance of Impression Liu Sanjie reflects the unique traditional culture of Chinese ethnic minorities in Guilin. Establishing humane tourist facilities, friendly tour guide services, a safe travel environment, and friendly local residents should all be noted as important factors influencing tourists' visits to promote sustainability in ecotourism destinations.

Tourists' behavioral decision-making is often subject to time and economic constraints, implying that tourists are likely to revisit when they have enough time and money. The tourism industry will be able to increase tourists' revisits through the development of cost-effective tourism products. Local and central governments need to improve transportation systems (e.g., express railway and direct international flights) to increase accessibility and shorten travel time. Government officials should keep in mind that ecotourists visit the destination to enjoy its natural and cultural attractions. In ecotourism destinations, tourism development should be implemented based on the government's guideline of sustainability to protect and preserve environmental and cultural resources. Thus, the promotion of ecotourism potentially contributes to sustainability by protecting natural resources, maintaining biodiversity, ensuring that local businesses and economy thrive, and supporting local communities $[21,25]$.

Tourists' ethics and environmental attitudes may impact the relationship between attitude towards an ecotourism destination and visitation. It is therefore suggested that future research should consider variables like pro-social behavior, environmental attitude, and tourist ethical judgment to extend the EMGB theory. As tourists have group differences in terms of gender, place of residence, and degree of pro-environmental attitude, it is recommended that future studies should consider multi-group analysis. Future studies should increase the sample size and collect a more homogeneous group of tourists by specifying their travel motivations, activities, or pro-environmental attitude. This study has a limitation in its data collection. The data were collected only in October, which is the most popular tourism season in Guilin. Considering potential seasonal effects on the quality of tourist experience, future studies should put more effort into collecting the data throughout the year and 
compare differences in peak and off-peak seasons. Moreover, longitudinal studies to track how the experience in nature could change tourists' attitudes and behavior would be interesting. To better understand the overall operating mechanism and linkage between sustainability and ecotourism, it is required to consider the diverse perspectives of local residents, governments, tourism suppliers, and other stakeholders on the sustainable development of Guilin's tourism.

Author Contributions: Conceptualization, Y.C.; Project administration, C.-K.L.; Writing-Original draft, M.-1.J.; Writing-Review \& editing, Y.C. and M.S.A. All authors have read and agreed to the published version of the manuscript.

Funding: This research received no external funding.

Conflicts of Interest: The authors declare no conflict of interest.

\section{References}

1. World Travel and Tourism Council. Global Economic Impact and Issues; World Travel and Tourism Council: London, UK, 2018.

2. Chen, G.; Dichter, A.; Saxon, S.; Suo, P.; Yu, J. Huānyíng to the New Chinese Traveler. Available online: https://www.mckinsey.com/industries/travel-transport-and-logistics/our-insights/huanying-to-thenew-chinese-traveler (accessed on 24 April 2019).

3. Ministry of Culture and Tourism of the People's Republic of China. The Basic Situation of the Tourism Market in 2018. Available online: http://zwgk.mct.gov.cn/auto255/201902/t20190212_837271.html?keywords= (accessed on 17 May 2019).

4. Ministry of Culture and Tourism. Guidelines on Promoting Sustainable Development of Rural Tourism. 2018. Available online: http://zwgk.mct.gov.cn/auto255/201812/t20181211_836468.html?keywords= (accessed on 17 May 2019).

5. General Office of the State Council. Guidance on Promoting All-For-One Tourism Development. Available online: https://baijiahao.baidu.com/s?id=1595700916192295396\&wfr=spider\&for=pc (accessed on 13 November 2019).

6. UNESCO. World Heritage List. Available online: http://whc.unesco.org/en/list (accessed on 30 August 2020).

7. UNWTO. Sustainable Tourism Observatories. Available online: http://www.mcsto.org/sunshine.asp?1-10370-0-.html (accessed on 30 August 2020).

8. FAO. GIAHS List. Available online: http://www.fao.org/home/common-elements/top-navigation-content/ resources/en/ (accessed on 30 August 2020).

9. Guilin Culture; Broadcasting and TV; Tourism Bureau. Tourism Main Indicators Data Bulletin in 2018. Available online: http://www.gltour.gov.cn/lygz/lytj/201903/t20190321_1101849.html (accessed on 1 June 2019).

10. Li, X.R.; Chen, G.H. Debates and boundaries: A commentary on developing tourism-related indigenous research in China. Tour. Trib. 2019, 34, 12-20.

11. Zhang, W.J. Study of the life cycle of tourist destination definition and redefinition-A case study of Guilin. Tour. Forum. 2014, 7, 13-20.

12. Jin, M.; Li, X.; Wu, L. A comparative analysis on tourist's revisit intention based on the theory of reasoned action, theory of planned behavior, and model of goal-directed behavior. Tour. Forum. 2019, 12, 33-40.

13. Fishbein, M. An Investigation of the Relationships between Beliefs about an Object and the Attitude toward that Object. Hum. Relat. 1963, 16, 233-239. [CrossRef]

14. Perugini, M.; Bagozzi, R.P. The role of desires and anticipated emotions in goal-directed behaviours: Broadening and deepening the theory of planned behaviour. Br. J. Soc. Psychol. 2001, 40, 79-98. [CrossRef]

15. Ji, C.L.; Nie, Y.K. Chinese tourists' gaming consumer behavioral intent and its influencing factors: An empirical test based on MGB theory. Tour. Trib. 2017, 32, 37-46.

16. Song, H.J.; Lee, C.K.; Kang, S.K.; Boo, S.J. The effect of environmentally friendly perceptions on festival visitors' decision-making process using an extended model of goal-directed behaviour. Tour. Manag. 2012, 33, 417-428. [CrossRef]

17. Song, H.S.; Lee, C.K.; Reisinger, Y.; Xu, H.L. The role of visa exemption in Chinese tourists' decision-making: A model of goal-directed behavior. J. Travel Tour. Mark. 2016, 34, 1-14. [CrossRef] 
18. Teh, L.; Cabanban, A.S. Planning for sustainable tourism in southern Pulau Banggi: An assessment of biophysical conditions and their implications for future tourism development. J. Environ. Manag. 2007, 85, 999-1008. [CrossRef]

19. Blamey, R.K. Principles of Ecotourism. In Encyclopedia of Ecotourism; Weaver, D.B., Ed.; CABI Publishing: New York, NY, USA, 2001; pp. 5-21.

20. Wall, G. FORUM: Is Ecotourism Sustainable? Environ. Manag. 1997, 21, 483-491. [CrossRef]

21. Hall, C.M.; Lew, A.A. Sustainable Tourism: A Geographical Perspective; Longman: Harlow, UK, 1998.

22. Wondirad, A.; Tolkach, D.; King, B. Stakeholder collaboration as a major factor for sustainable ecotourism development in developing countries. Tour. Manag. 2020, 78, 104024. [CrossRef]

23. Lee, J.H. Conflict mapping toward ecotourism facility foundation using spatial Q methodology. Tour. Manag. 2019, 72, 69-77. [CrossRef]

24. Beaumont, N. Ecotourism and the Conservation Ethic: Recruiting the Uninitiated or Preaching to the Converted? J. Sustain. Tour. 2001, 9, 317-341. [CrossRef]

25. Drumm, A.; Moore, A. An Introduction to Ecotourism Planning. In Ecotourism Development-A Model for Conservation Planners and Mangers; The Nature Conservancy: Arlington, VA, USA, 2005.

26. Van der Pligt, J.; de Vries, N.K. Expectancy-Value models of health behavior: The role of salience and anticipated affect. Psychol. Health 1998, 13, 289-305. [CrossRef]

27. Song, H.J.; Lee, C.K.; Norman, W.C.; Han, H. The role of responsible gambling strategy in forming behavioral intention: An application of a model of goal-directed behavior. J. Travel Res. 2012, 51, 512-523. [CrossRef]

28. Lee, C.K.; Ko, S.K.; Lim, S.H. A study on the behavioral intention of horseback riding experience using the model of goal-directed behavior: Focusing on youths' horseback riding experiences as perceived by parents. Int. J. Tour. Hosp. Res. 2017, 31, 5-19.

29. Hunt, J.D. Image as a Factor in Tourism Development. J. Travel Res. 1975, 13, 1-7. [CrossRef]

30. Lin, C.T.; Huang, Y.L. Mining tourist imagery to construct destination image position model. Expert Syst. Appl. 2009, 36, 2513-2524. [CrossRef]

31. Crouch, G.I. Destination competitiveness: An analysis of determinant attributes. J. Travel Res. 2011, 50, 27-45. [CrossRef]

32. Chen, C.F.; Phou, S. A closer look at destination: Image, personality, relationship and loyalty. Tour. Manag. 2013, 36, 269-278. [CrossRef]

33. Mansfeld, Y. The role of security information in tourism crisis management: The missing link. In Tourism, Security and Safety from Theory to Practice; Mansfeld, Y., Pizam, A., Eds.; Elsevier: Amsterdam, The Netherlands, 2006; pp. 271-290.

34. Baloglu, S.; Mccleary, K.W. US International pleasure travelers' image of four Mediterranean destinations: A comparison of visitors and non- visitors. J. Travel Res. 1999, 38, 144-152. [CrossRef]

35. Prayag, G. Tourists' evaluations of destination image, satisfaction, and future behavior intention: The case of Maurtius. J. Travel Tour. Mark. 2009, 26, 36-53. [CrossRef]

36. Cheng, P.F. Effect of tourists' pre-visit destination image on their perceived service quality: The moderating effect of tourist's expertise. Tour. Trib. 2017, 33, 57-66.

37. Gallarza, M.G.; Saura, I.G.; Garcia, H.C. Destination image: Toward a conceptual framework. Ann. Tour. Res. 2002, 29, 56-78. [CrossRef]

38. Fakeye, P.C.; Crompton, J.L. Image Differences between Prospective, First-Time, and Repeat Visitors to the Lower Rio Grande Valley. J. Travel Res. 1991, 30, 10-16. [CrossRef]

39. Xie, K.L.; Lee, J.S. Toward the perspective of cognitive destination image and destination personality: The case of Beijing. J. Travel Tour. Mark. 2013, 30, 538-556. [CrossRef]

40. Agapito, D.; Valle, P.; Mendes, J. The cognitive-affective-conative model of destination image: A confirmatory analysis. J. Travel Tour. Mark. 2013, 30, 471-481. [CrossRef]

41. Song, H.; You, G.J.; Reisinger, Y.; Lee, C.K.; Lee, S.K. Behavioral intention of visitors to an Oriental medicine festival: An extended model of goal directed behavior. Tour. Manag. 2014, 42, 101-113. [CrossRef]

42. Jalilvand, M.R.; Samiei, N.; Dini, B.; Manzari, P.Y. Examining the structural relationships of electronic word of mouth, destination image, tourist attitude toward destination and travel intention: An integrated approach. J. Destin. Mark. Manag. 2012, 1, 134-143. [CrossRef] 
43. Park, S.H.; Hsieh, C.M.; Lee, C.K. Examining Chinese College Students' Intention to Travel to Japan Using the Extended Theory of Planned Behavior: Testing Destination Image and the Mediating Role of Travel Constraints. J. Travel Tour. Mark. 2016, 34, 113-131. [CrossRef]

44. Guido, G.; Prete, M.I.; Peluso, A.M. The role of ethics and product personality in the intention to purchase organic food products: A structural equation modeling approach. Int. Rev. Econ. 2012, 57, 79-102. [CrossRef]

45. Page, T. Product attachment and replacement: Implications for sustainable design. Int. J. Sustain. Des. 2014, 2, 265-281. [CrossRef]

46. Tuan, Y.F. Space and Place: The Perspective of Experience; University of Minnesota Press: Minneapolis, MN, USA, 1977.

47. Williams, D.R.; Roggenbuck, J.W. Measuring place attachment: Some preliminary results. In Abstracts: 1989 Leisure Research Symposium, Proceedings of the Outdoor Planning and Management NRPA Symposium on Leisure Research, San Antonio, TX, USA, 20-22 October 1989; National Recreation and Park Association: Alexandria, VA, USA, 1989.

48. Tsai, S.P. Place attachment and tourism marketing: Investigating international tourists in Singapore. Int. J. Tour. Res. 2012, 14, 139-152. [CrossRef]

49. Brehim, J.; Eisenhauer, B.; Krannich, R. Community attachment as predictors of local environmental concern, the case for multiple dimensions of attachment. Am. Behav. Sci. 2006, 50, 142-165. [CrossRef]

50. Sheng, T.T.; Yang, Z. Research process and enlightenment on sense of place in foreign countries. Hum. Geogr. 2015, 130, 11-17.

51. Stylidis, D. Using Destination Image and Place Attachment to Explore Support for Tourism Development: The Case of Tourism Versus Non-tourism Employees in EILAT. J. Hosp. Tour. Res. 2020, 44, 951-973. [CrossRef]

52. Bailey, A.A. Place attachment and post-disaster decision-making in a second home context: A conceptual framework. Curr. Issues Tour. 2020, 23, 1205-1215.

53. Veasna, S.; Wu, W.Y.; Huang, C.H. The impact of destination source credibility on destination satisfaction: The mediating effects of destination attachment and destination image. Tour. Manag. 2013, 36, 511-526. [CrossRef]

54. Kaplanidou, K.; Jordan, J.S.; Funk, D.; Ridinger, L.L. Recurring sport events and destination image perceptions: Impact on active sport tourist behavioral intentions and place attachment. J. Sport Manag. 2012, 26, 237-248. [CrossRef]

55. Prayagl, G.; Ryan, C. Antecedents of tourists' loyalty to Mauritius: The role and influence of destination image, place attachment, personal involvement, and satisfaction. J. Travel Res. 2012, 51, 342-356. [CrossRef]

56. Hou, J.; Lin, C.; Morais, D.B. Antecedents of attachment to a cultural tourism destination: The case of Hakka and non-Hakka Taiwanese visitors to Pei-Pu, Taiwan. J. Travel Res. 2005, 44, 221-233. [CrossRef]

57. Brown, G.; Smith, A.; Assaker, G. Revisiting the lost city: An empirical examination of sport involvement, place attachment, event satisfaction and spectator intentions at the London Olympics. Tour. Manag. 2013, 55, 160-172. [CrossRef]

58. Walker, G.J.; Chapman, R. Thinking like a park: The effects of sense of place, perspective-taking, and empathy on pro-environmental intentions. J. Park Recreat. Adm. 2003, 21, 71-86.

59. Halpenny, E. Pro-environmental behaviors and park visitors: The effect of place attachment. J. Environ. Psychol. 2010, 30, 409-421. [CrossRef]

60. Kelly, G.; Hosking, K. Nonpermanent residents, place attachment, and "sea change" communities. Environ. Behav. 2008, 40, 575-594. [CrossRef]

61. Ramkissoon, H. Authenticity, satisfaction, and place attachment: A conceptual framework for cultural tourism in African island economies. Dev. S. Afr. 2015, 32, 292-302. [CrossRef]

62. Huang, C.H.; Li, J.Z.; Zhou, X.J. Study on impact of travel intention: An empirical study facing public health emergency. Hum. Geogr. 2015, 130, 145-150.

63. Esposito, G.; van Bavel, R.; Baranowski, T.; Duch-Brown, N. Applying the model of goal-directed behavior, including descriptive norms, to physical activity intentions: A contribution to improving the theory of planned behavior. Psychol. Rep. 2016, 119, 5-26. [CrossRef]

64. Han, H.; Ryu, K. The theory of repurchase decision-making (TRD): Identifying the critical factors in the post-purchase decision-making process. Int. J. Hosp. Manag. 2012, 31, 786-797. [CrossRef] 
65. Kim, M.J.; Lee, M.J.; Lee, C.K.; Song, H.J. Does gender affect Korean tourists' overseas travel? Applying the model of goal-directed behavior. Asia Pac. J. Tour. Res. 2012, 17, 509-533. [CrossRef]

66. Guilin Municipal People's Government. 2014 Guilin Economic and Social Statistical Yearbook; Guilin Municipal People's Government: Guilin, China, 2015.

67. Lee, C.K.; Lee, Y.K.; Lee, B.K. Korea's destination image formed by the 2002 World Cup. Ann. Tour. Res. 2005, 32, 839-858. [CrossRef]

68. Lee, J.J.; Kyle, G.; Scott, D. The mediating effect of place attachment on the relationship between festival satisfaction and loyalty to the festival hosting destination. J. Travel Res. 2012, 51, 754-767. [CrossRef]

69. Lee, C.K. Tourism Research and Statistical Analysis; Daewangsa: Seoul, Korea, 2017.

70. Hu, L.; Bentler, P.M. Cutoff criteria for fit indexes in covariance structure analysis: Conventional criteria versus new alternatives. Struct. Equ. Modeling. 1999, 6, 1-55. [CrossRef]

71. Anderson, J.C.; Gerbing, D.W. Assumptions and comparative strengths of the two-step approach: Comment on Fornell and Yi. Sociol. Methods Res. 1992, 20, 321-333. [CrossRef]

(C) 2020 by the authors. Licensee MDPI, Basel, Switzerland. This article is an open access article distributed under the terms and conditions of the Creative Commons Attribution (CC BY) license (http://creativecommons.org/licenses/by/4.0/). 